\title{
365. Klinische und experimentelle Untersuchungen an Kava-Kathetern
}

\author{
A. Anders ${ }^{1}$, M. Piepenbrock ${ }^{2}$, M. Willenbrink ${ }^{2}$, S. Frieler ${ }^{2}$ und O. Krüger $^{3}$ \\ ${ }^{1}$ Chirurgische Klinik I, Stadtkrankenhaus Offenbach, D-6050 Offenbach/Main, ${ }^{2}$ Institut für Anaesthesiologie, \\ Klinikum Steglitz der FU Berlin und ${ }^{3}$ Bundesanstalt für Materialprüfung, Berlin
}

\section{Clinical and Experimental Properties of Vena cava Catheters}

Summary. A total of 180 jugular-venous cathethers (Cavafix Certo GS, Frekathether Pur, Vygoflex-in, Alpha Set J 30) were clinically tested under prospective standardized conditions (experimental flow, elasticity, thrombin-formation, X-ray contrast, puncture characteristics) Polyurethane (Cavafix Certo, Frekatheter Pur) proved to be of a high quality, especially with respect to flow and thrombin-producing ability. Vena cava catheters, with laterally situated outflow holes, have an increased outflow area and are therefore superior to the other catheters in this respect. The polyethylene catheters showed increased activity during radio-fibrinogen testing in vitro - a sign of thrombin formation.

Key words: Vena cava cathether - Prospective study - Material characteristics - Clinical value.

Zusammenfassung. 180 Vena jugularis-Kathether wurden unter prospektiv standardisierten Bedingungen klinisch getestet (Cavafix Certo GS, Frekatheter Pur, Vygoflex-in, Alpha Set J 30) (Strömungsverhalten experimentell, Elastizität, Thrombogenizität, Röntgenkontrastfähigkeit, Punktionseigenschaften) Polyuretan (Cavafix Certo, Frekatheter Pur) zeigten ein überlegenes Materialverhalten, insbesondere bei der Überprüfung der Durchflußmenge und der Thrombogenizität. Kava-Katheter mit seitlichen Öffnungslöchern haben eine günstige Raumwinkelverbreiterung und sind strömungsdynamisch endständigen Kathetern überlegen. Bei der Radiofibrinogentestung in vitro bestand bei Polyäthylen-Kathetern bei allen Kathetern eine erhöhte Aktivität als Zeichen einer Thrombenbildung.

Schlüsselwörter: Kava-Katheter - Prospektive Studie - Materialeigenschaften - Klinische Wertigkeit.

\section{Die postoperative Veränderung der Reißfestigkeit von Duratransplantaten}

\author{
H. H. Werner und M. Nagelschmidt
}

2. Lehrstuhl für Chirurgie, Köln-Merheim, Ostmerheimer Straße 200, D-5000 Köln 51

\section{Postoperative Variations in Tensile Strength of Dura Transplant}

\begin{abstract}
Summary. Human dura is commercially available under the following names: Lyodura, Lyodura soft and Tutoplast. 60 strips of each kind $(10 \times 1 \mathrm{~cm})$ were implanted subcutaneously in the back of rabbits. The tensile strength of the transplants was measured prior to operation and after specimens had been removed 1, 4, 7, 14, 21 and 31 days after operation. The tensile strength varied from 1.5 to $4 \mathrm{kp}$. The loss of stability during the observation period was not significant. The tensile strength of Lyodura "soft" is approximately double the values obtained for the two other kinds of dura.
\end{abstract}

Key words: Dura mater - Tensile strength - Postoperative.

Zusammenfassung. Menschliche Dura ist im Handel in den Modifikationen Lyodura, Lyodura soft und Tutoplast erhältlich. Von jeder Sorte wurden jeweils 60 Streifen der Größe $10 \times 1 \mathrm{~cm}$ subcutan am Rücken von Kaninchen implantiert. Die Reißfestigkeit der Transplantate wurde präoperativ und nach Entnahme am 1., 4., 7., 14., 21. und 31. Tag gemessen. Sie beträgt etwa 1,5 bis $4 \mathrm{kp}$. Der Festigkeitsabfall über die Zeit ist nicht signifikant. Die Reißfestigkeit von Lyodura ,,soft" ist etwa doppelt so hoch wie die der beiden anderen Durasorten.

Schlüsselwörter: Dura mater - Reißfestigkeit - Postoperativ. 